\title{
Suomen kuntien sosiaalisen rakenteen perustekijät
}

\author{
Valtiot.tri PAAVO PIEPPONEN \\ Väestöpoliittinen Tutkimuslaitos
}

\section{Johdanto}

Maassamme on suoritettu lukuisia tutkimuksia, joissa on kuvattu erilaisten sosiaalisten, taloudellisten ja poliittisten ilmiöiden alueellista jakaantumista. Aluetutkimuksen päämääränä on tavallisesti luoda aluejakoja tai suorittaa jo laaditun aluejaon puitteissa sosiaalitutkimusta. Useissa tutkimuksissa nämä päämäärät on pyritty toteuttamaan samalla kertaa.

Aluejakoa voidaan suorittaa monien kriteerien mukaan. Hustich on erottanut kolme periaatetta: hallinnollinen jako, muodollinen jako yhtenäisiin eli homogeenisiin alueisiin ja toiminnallinen jako (Hustich, s. 229). Hallinnollisesta aluejaosta mainittakoon maan jako lääneihin ja kuntiin. Koska meillä kaikki tärkeimmät tilastot aivan viime aikoihin asti on kerätty lääneittäin tai kunnittain, on monissa sosiaalitutkimuksissa ollut pakko käyttää hallinnollista aluejakoa, vaikka se ei usein olisikaan tarkoituksenmukaisin. Myös homogeenisia ja toiminnallisia aluejakoja suoritettaessa on ollut käytettävä hallinnollista jakoa ja eri kriteereiden mukaan on sitten muodostettu homogeeniset tai toiminnalliset aluejaot.

Muodollinen eli homogeeninen alue on rajoitettu siten, että se jonkin ominaisuuden puolesta on samankaltainen kauttaaltaan. Tällä tavoin suoritetuista aluejaoista mainittakoon tulotasoalueet (Wahlbeck) ja työttömyysalueet (Pulkkinen). Toiminnallinen alue taasen rajoitetaan siten, että sen muodostaa keskus ja sitä ympäröivä vaikutusalue. Esimerkkeinä toiminnallisista alueista ovat Valtakunnansuunnittelutoimiston käyttämät talousalueet ja Erva-Latvala OY:ssä laadittu markkinointialuejako.

Aluetutkimuksen toisena tehtävänä on laadittujen aluejakojen puitteissa tutkia sosiaalisten, taloudellisten ja poliittisten ilmiöiden levinneisyyttä ja siihen vaikuttavia tekijöitä. Mainittakoon vain tämän vuosikirjan edellisessä niteessä olleet tutkimukset mies- ja naisenemmyydestä Suomen maalaiskunnissa (Alameri), maassamuuton voimakkuudesta ja suunnasta ( $\mathrm{Pu}$ rola) ja aviollisen hedelmällisyyden vaihteluista (Hartman ja Puumalainen). Ensiksi mainitussa tutkimuksessa kuvattin ilmiöiden esiintymistä 
kunnittain, toisessa talousalueittain. Kolmannessa tutkimuksessa pyrittiin etsimään aviollisen hedelmällisyyden syy-yhteyksiä. Samalla nämä kolme tutkimusta ovat esimerkkejä eri tavoin käytetyistä aluejaoista. Alameri muodosti homogeenisia alueita, Purola tutki maassamuuttoa talousalueittain, siis toiminnallisen aluejaon puitteissa ja Hartman ja Puumalainen tutkivat hedelmällisyyttä lääneittäin, siis hallinnollisen aluejaon mukaan.

\section{Tutkimustehtävä}

Sosiaaliekologian keskeisiä ongelmia on alueellisen erilaistumisen tutkiminen. Alueellinen erilaistuminen on tulos lajien ja organismien välisestä kilpailusta, joka johtaa siihen, että kukin organismi ja laji joutuu sijoittumaan toimintakykyään vastaavaan ympäristöön (Allardt \& Littunen, s. 275). Siten sosiaaliekologian tehtävänä on tutkia maantieteellisen ympäristön merkitystä ihmisten vuorovaikutuksessa.

Kuten mainittu, meillä on suoritettu lukuisia sosiaaliekologisia tutkimuksia. Meillä suoritetun aluetutkimuksen haittana kuitenkin voidaan pitää sitä, että tutkimuksissa on rajoituttu vain harvojen ilmiöiden samanaikaiseen analyysiin. Alueellista erilaistumista tutkittaessa on kuitenkin syytä suorittaa myös sellaista tutkimusta, jossa mahdollisimman runsasta tietomateriaalia hyväksi käyttäen voitaisiin päästä käsiksi niihin perustekijöihin, joiden suhteen erilaistumista tapahtuu. Näitä perustekijöitä voitaisiin käyttää sitten käsitteinä tutkittaessa muita ilmiöitä ja laadittaessa aluejakoja.

Tämän tutkimuksen tarkoituksena on etsiä niitä perustekijöitä, jotka aiheuttavat alueellista erilaistumista. Pyrkimyksenä on sosiaalisia, taloudellisia ja väestöllisiä tietoja analysoimalla yhdistää mahdollisimman runsas joukko muuttujia harvalukuisiksi perustekijöiksi. Tällainen tutkimusote tiivistää siten tietoja ja saattaa samalle perusulottuvuudelle sellaiset ilmiöt, jotka yhdyskunnissa liittyvät toisiinsa.

Tutkimuksen analyysiyksikkönä on kunta. Kunta on pienin alue, josta on saatavissa runsaasti tietoja. Kun vuoden 1960 väestölaskennan tulokset eivät vielä ole käytettävissä, on ollut pakko turvautua vuoden 1950 väestölaskenta-aineistoon. Tutkimusmateriaali on siten kymmenen vuotta vanha. Kun tutkimuksessa keskeisellä sijalla on variaabelien keskinäisten suhteiden selvittely, voidaan tämäntyyppisten tutkimusten materiaalina käyttää tuoreempien tietojen puutteessa vanhempaakin materiaalia. Kuitenkaan ei pidä unohtaa sitä mahdollisuutta, että variaabelien keskinäiset suhteet saattavat muuttua niin, että ilmaantuu uusia perustekijöitä tai että tiettyjen variaabelien merkitys muuttuu. Näin ollen tutkimus antaa siis kuvan siitä, millaiset ovat variaabelien keskinäiset suhteet Suomen kunnissa tämän vuosisadan puolivälissä. 
Analyysimenetelmä

Kun tutkimustehtävänä on perusulottuvuuksien etsiminen, on faktorianalyysi tarkoituksenmukaisin menetelmä. Faktorianalyysi suoritetaan muuttujien välisistä korrelaatiokertoimista siten, että muuttujat tiivistetään muutamiksi perusulottuvuuksiksi eli faktoreiksi, jotka ovat toisistaan suhteellisen riippumattomia. Tällä tavoin syntyy käsitteitä, joiden avulla tutkimusaineistoa on yksinkertaisempi kuvailla. Faktorianalyysi onkin sopiva menetelmä silloin, kun tarvitaan käsitejärjestelmä jonkin ilmiöpiirin kuvailua varten (Vahervuo \& Ahmavaara, s. 53). Tässä tutkimuksessa ilmiöpiirinä on alueellinen erilaistuminen, ja faktorianalyysi voi siten ikäänkuin tiivisteltynä valaista sitä sen sijaan, että tutkittaisiin erilaistumista kaikkien muuttujien suhteen erikseen.

Faktorianalyyttisissa tutkimuksissa muodostaa oman ongelmansa se, mitkä muuttujat tulisi ottaa analyysiin mukaan. Kun itse faktorianalyysi ei anna sääntöjä tähän, on variaabelien valinta tapahduttava muiden kriteereiden pohjalta. Tällöin on ensi sijassa otettava huomioon alan aikaisemmat tutkimustulokset.

\section{Teoreettinen tausta}

Tutkimuksen lähtökohtana on ollut se teoria, jonka Shevky ja Bell (1955) ovat kehittäneet tutkiessaan amerikkalaisen suurkaupungin alueellista erilaistumista. Vaikka lähtökohta on näin kaukana, tarjoaa heidän teoriansa kuitenkin sellaisia aineksia, joita voi soveltaa laajemmissa yhteisöissä ja toisissa sosiaalisissa järjestelmissä.

Shevky ja Bell esittävät aluksi kolme »teollisen yhteiskunnan postulaattia»: muutokset suhteiden laajuudessa ja intensiteetissä, tehtävien erilaistuminen ja organisaation kompleksisuus. Näistä postulaateista ei ole kuitenkaan suurta hyötyä, ennenkuin voidaan identifioida niihin liittyvät organisaatiomuodot. Tutkijat esittävät kolme toisiinsa liittyvää trendiä: 1) muutokset tietojen ja taitojen jakaantumisessa, 2) muutokset tuotannollisessa toiminnassa ja 3) muutokset väestön kokoomuksessa. Muutokset tietojen ja taitojen jakaantumisessa merkitsevät mm. käsityön merkityksen vähenemistä ja toisaalta kanslia-, valvonta- ja johtotehtävien merkityksen kasvamista. Tuotannollisen toiminnan tärkeimmät muutokset ovat alkutuotannon merkityksen väheneminen, kaupunkeihin keskittyvien suhteiden merkityksen kasvu ja ruokakunnan merkityksen väheneminen taloudellisena yksikkönä. Muutokset väestön kokoomuksessa tapahtuvat lisääntyvänä liikkuvuutena, muutoksina ikä- ja sukupuolijakautumissa ja lisääntyvänä moniaineksisuutena. Näissä kolmessa trendissä tapahtuvat muutokset kuvaavat tutkijoiden mielestä parhaiten nykyajan yhteiskunnan muuttuvaa luonnetta. Tiettyinä ajankohtina sosiaaliset järjestelmät ovat erilaisessa suhteessa näihin muutoksiin nähden. Esimerkkeinä tietyn sosiaali- 
sen järjestelmän rakenteellisista muutoksista tutkijat esittävät kolme muutossarjaa: muutokset ammattien ryhmittelyssä, muutokset elämäntavoissa ja väestön alueellinen uudelleenjakaantuminen.

Nämä kolme rakenteellista muutossarjaa vuorostaan määritellään uudelleen muutoksen rakenteellisina heijastumina, joita käytetään kuvailevina ja analyyttisina käsitteinä tutkittaessa nykyajan yhteiskunnan sosiaalista rakennetta. Ne ovat sosiaalinen asema (rank), kaupunkimaistuminen ja syrjintä. Toinen tutkijoista (Bell) käyttää nimityksiä taloudellinen asema (status), perheen asema ja etninen asema.

Seuraavana vaiheena Shevky ja Bell ovat valinneet joukon muuttujia, joista on muodostettu indeksejä kolmea faktoria varten. Ensimmäistä faktoria, sosiaalista asemaa, mittaamaan valittiin ammatti, koulusivistys ja vuokra. Toisen faktorin indeksin muodostivat hedelmällisyys, naistyövoima ja yhden perheen talot. Syrjintäfaktorin mittarina käytettiin neekereiden ja vähemmistökansallisuuksien osuutta väestöstä.

Shevkyn kehittämää järjestelmää on yhä useammin alettu käyttää kaupunkitutkimuksessa. On osoitettu, että indekseillä on melko muuttumaton faktorirakenne Yhdysvaltojen eri kaupungeissa (Van Arsdol, Camilleri \& Schmid). Shevkyn indeksejä on käytetty myös analyyttisina käsitteinä tutkittaessa kaupungin sisäistä alueellista erilaistumista testaamalla Burgessin vyöhykehypoteesia ja Hoytin sektorihypoteesia (Anderson \& Egeland).

Vaikka tutkimuksen lähtökohtana ovatkin ne ajatukset, joita Shevky työtovereineen esittää alueellisesta erilaistumisesta, ei tässä tutkimuksessa testata heidän indeksiensä yleispätevyyttä. Nehän ovat laaditut nimenomaan kaupungin ekologista analyysia varten. Tutkimus eroaa Shevkyn työstä myös siinä, että käsitteisiin pyritään faktorianalyyttista tietä eikä teoreettisen käsiteanalyysin kautta. Sitä vastoin muuttujien valintaan on edellä selostettu teoreettinen järjestelmä vaikuttanut suuresti.

\section{Muuttujat}

Vuoden 1950 yleisen väestölaskennan tulokset muodostavat pääasiallisimman tutkimusaineiston. Ne on julkaistu kaikkiaan kahdeksana niteenä (Suomen virallinen tilasto VI, Väestötilastoa, C 102). Lisäksi on turvauduttu eräisiin muihin lähteisiin, jotka on mainittu kunkin variaabelin yhteydessä. Korrelaatiokertoimet (tulomomenttikertoimia) laskettiin luokitellusta aineistosta. Liitteenä olevassa variaabelien luettelossa on ilmoitettu kunkin variaabelin alimmat ja ylimmät luokat arvoineen. On huomattava, että joskus on variaabeli »käännetty» valmiiksi, jotta korrelaatiokertoimet olisivat positiivisia. Niinpä esimerkiksi variaabelin 7 alin luokka käsittää ne kunnat, joissa maa- ja metsätalousväestön osuus on $90-100 \%$, mutta variaabelin 9 alimpaan luokkaan kuuluvat ne kunnat, joissa teollisuus- ja käsityöammateissa toimivia on alle $10 \%$ väestöstä. 
Korrelaatiokertoimet laskettiin IBM-650-tietokoneella. Kaikkiaan laskettiin 23 variaabelin keskinäiset kertoimet, mutta kolme muuttujaa jätettiin faktorianalyysista pois, koska korrelaatiokertoimet kaikkiin muuttujiin olivat varsin alhaiset.

\section{Faktorit ja niiden tulkinta}

Korrelaatiomatriisi, josta faktorointi aloitetaan, on liitetaulussa 1 (s. 44). Faktorointi on suoritettu Thurstonen sentroidimenetelmän mukaan ( $V a$ hervuo ja Ahmavaara, ss. 56-77). Kommunaliteeteiksi valittiin kunkin muuttujan suurin korrelaatio. Faktoroinnin lopputulos, sentroidimatriisi, ja kommunaliteetit $\left(\mathrm{h}^{2}\right)$ ovat liitetaulussa 2 (s. 44). Faktorointi lopetettiin jo kolmannen faktorin jälkeen, sillä kaikki residuaalikertoimet olivat varsin pieniä. Lisäksi havaitaan kommunaliteeteista, että kolme faktoria selittää kaikkien muuttujien varianssista enemmän kuin $50 \%$. Alin kommunaliteetti on näet .51 (muuttujalla 17).

Sentroidimatriisista ei kuitenkaan vielä voi suorittaa faktoreiden tulkintaa. Sitä varten on suoritettava rotaatio. Kun tutkimuksen tarkoituksena on ollut alueellisen erilaistumisen perusulottuvuuksien löytäminen, valittiin se rotaatiomenetelmä, joka parhaiten tarkoitusta varten soveltuu. Thurstonen kehittämä yksinkertaisen struktuurin periaate rotaatiossa toteuttaa sen, että saadaan esille mahdollisimman runsaasti nollalatauksia. Tämä muodollinen rotaatioperiaate helpottaa tulkintaa, ja on soveliain juuri silloin, kun pyritään luomaan käsitteitä, joita voi käyttää tutkimuksen analyysissa.

Rotaatio suoritettiin Ahmavaaran kehittämän analyyttisen kosiniratkaisun mukaan (Vahervuo \& Ahmavaara, ss. 90-100 ja 127-130). Rotaation tuloksena saatiin primäärifaktorimatriisi, joka on taulussa 1.

Faktoreiden tulkinnassa on muistettava, että osa muuttujista käännettiin luokitteluvaiheessa siten, että ylimpään luokkaan sijoitettiin ne kunnat, joissa kyseinen ominaisuus esiintyy vähäisenä (vrt. s. 37). Tällaiset käännetyt variaabelit ilmaistaan alempana olevissa luetteloissa merkinnällä (-).

I faktori. Muuttujat, joilla on I faktorilla lataus .30 tai sitä suurempi, ovat seuraavat:

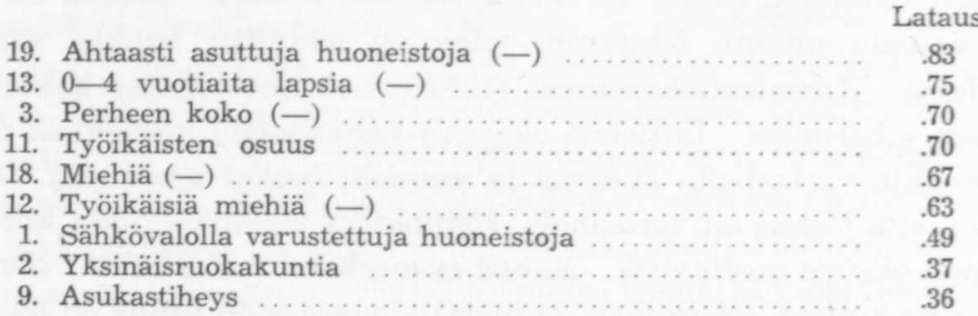

Ensimmäisellä faktorilla on runsaasti sellaisia variaabeleita, jotka liittyvät perheen ja väestön rakenteeseen sekä asumistasoon. Yhdyskunnalle, 
$\mathrm{T}$ a u lu 1. Primäärifaktorimatriisi.

Table 1. The Primary Factor Matrix.

\begin{tabular}{|c|c|c|c|c|}
\hline & & I & II & III \\
\hline & $\begin{array}{l}\text { Sähkövalolla varustettuja huoneistoja } \ldots \ldots \ldots \ldots \ldots \ldots \\
\text { Dwellings with electric light }\end{array}$ & .49 & .17 & .30 \\
\hline 2. & $\begin{array}{l}\text { Yksinäisruokakuntia } \ldots \ldots \ldots \ldots \ldots \ldots \ldots \ldots \ldots \ldots \ldots \ldots \ldots \ldots \\
\text { Households with one person }\end{array}$ & .37 & -.11 & .66 \\
\hline 3. & $\begin{array}{l}\text { Perheen koko } \ldots \ldots \ldots \ldots \ldots \ldots \ldots \ldots \ldots \ldots \ldots \ldots \ldots \ldots \ldots \ldots \ldots \\
\text { Family size }\end{array}$ & .70 & .24 & .17 \\
\hline 4. & $\begin{array}{l}\text { Tulot } \\
\text { Income }\end{array}$ & .25 & .14 & .56 \\
\hline 5. & $\begin{array}{l}\text { Yhden huoneiston asuinrakennuksia } \ldots \ldots \ldots \ldots \ldots \ldots \\
\text { One-family houses }\end{array}$ & .01 & .11 & .88 \\
\hline 6. & $\begin{array}{l}\text { Talon tai huoneiston omistajia } \ldots \ldots \ldots \ldots \ldots \ldots \ldots \ldots \ldots \\
\text { Home ownership }\end{array}$ & .03 & .21 & .80 \\
\hline & $\begin{array}{l}\text { Maa- ja metsätalousväestö } \ldots \ldots \ldots \ldots \ldots \ldots \ldots \ldots \ldots \ldots \ldots \\
\text { Farmers }\end{array}$ & .15 & .18 & .78 \\
\hline 8. & $\begin{array}{l}\text { Teollisuus- ja käsityöväestö } \ldots \ldots \ldots \ldots \ldots \ldots \ldots \ldots \ldots \ldots \ldots \ldots \\
\text { Industrial population }\end{array}$ & .10 & .45 & .46 \\
\hline 9. & $\begin{array}{l}\text { Asukastiheys } \ldots \ldots \ldots \ldots \ldots \ldots \ldots \ldots \ldots \ldots \ldots \ldots \ldots \ldots \ldots \ldots \\
\text { Population density }\end{array}$ & .36 & .30 & .52 \\
\hline & $\begin{array}{l}\text { Kauppa-, liikenne- ja palveluväestö } \ldots \ldots \ldots \ldots \ldots \ldots . \ldots . \ldots . \ldots . \ldots \\
\text { Commerce, transportation, communication and services }\end{array}$ & .19 & -.13 & .80 \\
\hline & $\begin{array}{l}\text { Työikäisten osuus } \ldots \ldots \ldots \ldots \ldots \ldots \ldots \ldots \ldots \ldots \ldots \ldots \\
\text { Population in the working ages }\end{array}$ & .70 & .22 & .22 \\
\hline & $\begin{array}{l}\text { Työikäisiä miehiä } \ldots \ldots \ldots \ldots \ldots \ldots \ldots \ldots \ldots \ldots \ldots \ldots \ldots \ldots \ldots \ldots \ldots \\
\text { Male population in the working ages }\end{array}$ & .63 & -.01 & .49 \\
\hline 13. & $\begin{array}{l}0-4 \text { vuotiaita lapsia } \ldots \ldots \ldots \ldots \ldots \ldots \ldots \ldots \ldots \ldots \ldots \ldots \ldots \ldots \ldots \ldots \\
\text { Children under } 5 \text { years }\end{array}$ & .75 & .19 & .11 \\
\hline 14. & $\begin{array}{l}\text { Asuinpaikkakunnalla syntyneitä } \ldots \ldots \ldots \ldots \ldots \ldots \ldots \ldots \ldots \ldots \ldots \\
\text { Proportion of persons living in the birth community }\end{array}$ & .08 & .67 & .32 \\
\hline 15. & 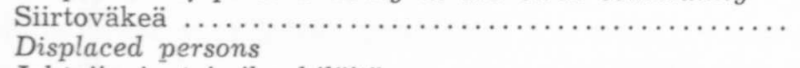 & .00 & .71 & .00 \\
\hline 16. & $\begin{array}{l}\text { Johtajia ja toimihenkilöitä } \ldots \ldots \ldots \ldots \ldots \ldots \ldots \ldots \ldots \ldots \ldots \ldots \ldots \ldots \\
\text { Managers, administrative and clerical employees }\end{array}$ & .00 & .00 & .92 \\
\hline 17. & $\begin{array}{l}\text { Kuntaan ja kunnasta muuttaneita } \ldots \ldots \ldots \ldots \ldots \ldots \ldots \\
\text { In- and out-flow migration }\end{array}$ & -.07 & .67 & .14 \\
\hline 18. & $\begin{array}{l}\text { Miehiä } \ldots \ldots \ldots \ldots \ldots \ldots \ldots \ldots \ldots \ldots \ldots \ldots \ldots \ldots \ldots \ldots \ldots \ldots \ldots \ldots \ldots \\
\text { Proportion of males }\end{array}$ & .67 & -.06 & .44 \\
\hline 19. & $\begin{array}{l}\text { Ahtaasti asuttuja huoneistoja } \ldots \ldots \ldots \ldots \ldots \ldots \ldots \ldots \ldots \\
\text { Overcrowded dwellings }\end{array}$ & .83 & .00 & .00 \\
\hline 20. & $\begin{array}{l}\text { Keskikoulututkinnon vv. } 1954-56 \text { suorittaneita ....... } \\
\text { Proportion of persons having completed junior high } \\
\text { school in } 1954-56\end{array}$ & .24 & -.01 & .72 \\
\hline
\end{tabular}

jolla on korkea pistemäärä tällä faktorilla, on luonteenomaista 1. että perheet ovat pieniä ja hedelmällisyys on alhainen, 2. että väestössä työikäiset (15-64-vuotiaat) ja naiset ovat suhteellisen runsaasti edustettuna ja 3 . että asumistaso on korkea. Faktoria voitaisiin siten nimittää väestön kaupunkimaisuudeksi, sillä nämä väestölliset ominaisuudet ovat tyypillisiä kaupungeille. Näin ei kuitenkaan ole paikallaan tehdä, sillä tässä ei ilmeisesti ole kyse kaupunkimaisuudesta, koska sitä kuvastavat paremmin kolmannen faktorin variaabelit. Kun perheen koko ja pienten lasten määrä ovat tämän faktorin avainvariaabeleita, on syytä nimittää tämä ulottuvuus pienperheisyydeksi. 
I I f a k t o ri. Toisen faktorin korkeat lataukset ovat seuraavilla muuttujilla:
15. Siirtoväkeä
14. Asuinpaikkakunnalla syntyneitä $(-)$
.71
17. Kuntaan ja kunnasta muuttaneita
8. Teollisuus- ja käsityöväestö
9. Asukastiheys
.67
.67
.45
.30

Lataus

Toisen faktorin korkeimmat lataukset ovat muuttujilla, jotka osoittavat väestön liikkuvuutta. Siirtoväen runsaus, muualta tulleiden suuri osuus ja kuntaan ja kunnasta muuttaneiden suuri osuus väestöstä antaakin aiheen nimittää tämän faktorin muuttoliike-faktoriksi. Korkeat lataukset variaabeleilla 8 ja 9 ilmaisevat, että muuttoliike teollisuuspaikkakunnilla ja tiheään asutuilla paikkakunnilla on vilkkainta.

I I f a ktori. Tällä faktorilla 14 variaabelia saa korkeat lataukset. Ne ovat seuraavat:

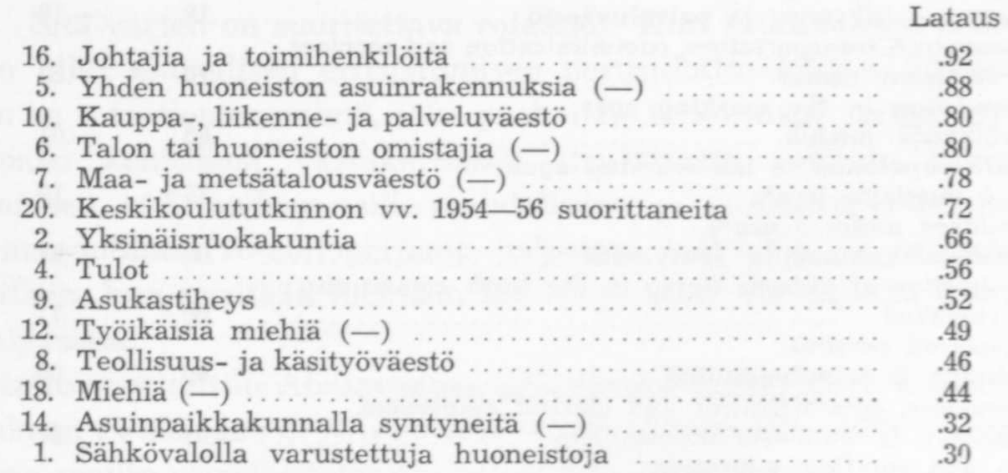

Tämä faktori on epäilemättä kaupunkimaisuutta-maaseutumaisuutta osoittava ulottuvuus. Sitä osoittavat korkeat lataukset ammattirakenteen variaabeleilla 16, 10, 7 ja 8 . Kerrostalojen runsaus (5) ja asunnon omistavien vähyys kuvastaa myös kaupunkimaista asumismuotoa. Ainoa sivistystason mittari, keskikoulun käyneiden osuus, saa myös korkean latauksen tällä faktorilla. Kaupunkimaiseen elämänmuotoon liittyy vielä yksinäisten ihmisten muodostamien ruokakuntien runsaus sekä tulojen suuruus. Lisäksi asukastiheys saa kolmannella faktorilla suurimman latauksen. Muut kolmannen faktorin variaabelit, lukuunottamatta variaabelia 8 , ovatkin sellaisia, että niillä on korkeampi lataus joko ensimmäisellä tai toisella faktorilla.

Kolmatta faktoria voitaisiin hyvällä syyllä sanoa yleisfaktoriksi, sillä 20 :stä variaabelista 14 saa latauksen .30 tai sitä suurempi. Kuitenkin merkitsevien latausten puuttuminen eräillä perhe- ja ikärakennetta sekä muuttoliikettä koskevilla muuttujilla viittaa siihen, että pienperheisyys ja muuttoliike ovat eriytyneet kaupunkimaisuuden faktorista. Nämä aiheuttavat 
siten alueellista erilaistumista eri ulottuvuuksilla. Myös voidaan sanoa, että pienperheisyys ja muuttoliike ovat riippumattomia urbaanisuuden asteesta. Toisin sanoen urbaanisilla alueilla on suuria ja pieniä perheitä sekä vilkasta ja vähäistä muuttoliikettä.

On mielenkiintoista verrata tässä saavutettuja empiirisiä tuloksia aikaisempiin teoreettisiin esityksiin ja empiirisiin tuloksiin. Jos verrataan tässä tutkimuksessa saatuja perustekijöitä niihin teoreettisesti johdettuihin käsitteisiin, joita Shevky ja Bell ovat esittäneet, voidaan niissä havaita vastaavuutta. Ensiksikin Shevkyn ja Bellin järjestelmän sosioekonominen asema vastannee lähinnä tämän tutkimuksen kolmatta faktoria. Tässä siihen kyllä sisältyy muitakin aineksia kuin sosiaalista statusta osoittavia muuttujia. Sitä vastoin toinen Shevkyn ja Bellin käsite, urbanisoituminen tai perheen asema vastaa lähinnä tämän tutkimuksen ensimmäistä faktoria. Kummallekin faktorille on ominaista perheen kokoa ja hedelmällisyyttä mittaavat muuttujat sekä ikä- ja sukupuolijakautumat. Tässä tutkimuksessa faktoria ei ole kuitenkaan nimitetty kaupunkimaisuudeksi, koska mielestäni kolmas faktori on selvimmin sitä. Shevkyn ja Bellin kolmas käsite, segregaatio on heijastuma väestön kokoomuksen muutoksista ja väestön uudelleen jakaantumisesta. Sama ilmiö tulee tämän tutkimuksen toisen faktorin osalle. Sehän sisältää miltei yksinomaan väestön uudelleen jakaantumisen muuttujia.

Eräs äskettäin julkaistu faktorianalyyttinen tutkimus Ohion valtion itsehallintoalueista (counties) osoittaa myös eräissä suhteissa yhdensuuntaisia tuloksia tässä suoritetun analyysin kanssa (Jonassen). Mainitussa tutkimuksessa, jossa analysoitiin 82 variaabelia, ilmeni vahva yleisfaktori, jolle annettiin nimeksi urbanismi. Samassa tutkimuksessa myös muuttoliike muodosti oman faktorinsa eikä liittynyt urbanismin faktoriin.

Tästä voidaan tehđä se johtopäätös, että muuttoliikkeen selvittämiseksi tarvitaan muitakin kuin kaupunkimaisuutta ilmaisevia muuttujia. On yleensä pyritty ajattelemaan muuttoliikettä maaseudun ja kaupungin elinkeinorakenteen aiheuttamana liikkeenä, mutta empiiriset tulokset osoittavat kuitenkin, että kaupunkimaisuus ei pysty tyydyttävästi selittämään muuttoliikettä.

Toinen tärkeä havainto on se, että myös väestön kokoomus vaihtelee riippumatta kaupunkimaisuusasteesta. Väestön kokoomuksessa perheen koko ja hedelmällisyys muodostavat ilmiön, jota voitaisiin sanoa familismiksi. Lienee yleisesti tunnettu, että kaupunkiperheet ovat pieniä ja hedelmällisyys alhainen. Tarkemmat tutkimukset osoittavat kuitenkin, että lapsiluku ei liity lineaarisesti kaupunkimaisuusasteeseen tai korkeaan sosiaaliseen asemaan. Meilläkin on tämän vuosikirjan edellisessä niteessä osoitettu, että perheen kokoa koskevat ihanteet vaihtelevat teollistumisasteen mukaan siten, että teollistuvassa yhteiskunnassa ihanteena on pieni perhe, mutta jo teollistuneessa tai modernissa yhteiskunnassa lapsiluku 
$\mathrm{T}$ a u lu 2. Faktorien interkorrelaatiot.

T a ble 2. Intercorrelations of the factors.

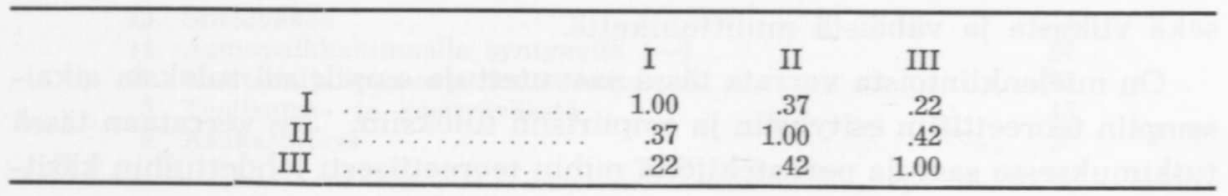

pyrkii kohoamaan. Siten tämä uusien ihanteiden ilmaisema suhde näkyy jo tämän vuosisadan puolivälin sosiaalianalyysissa (Hartman ja Puumalainen).

Tutkimuksessa havaittujen faktorien interkorrelaatiot osoittavat kuitenkin, että kaikki kolme faktoria korreloivat positiivisesti. Siten pienperheisyys, muuttoliike ja kaupunkimaisuus näyttävät kyllä liittyvän toisiinsa, mutta varsinkin pienperheisyyden ja kaupunkimaisuuden välinen korrelaatio on alhainen kuten taulusta 2 havaitaan.

Asiaa valaisee myös kunkin faktorin riippuvuus muista faktoreista eli faktorin ja muiden faktorien väliset yhteiskorrelaatiot. $\mathrm{Ne}$ on laskettu faktorikorrelaatioiden inverssimatriisista (Markkanen, s. 17). Faktorin I yhteiskorrelaatio muihin faktoreihin on .375 , faktorin II .502 ja faktorin III 417. Tämä merkitsee, että pienperheisyys on riippumattomin ja muuttoliike riippuvaisin muista faktoreista. Riippumattoman varianssin määrä faktoreittain on I $86 \%$, II $75 \%$ ja III $83 \%$.

\section{Loppusanat}

Suomen kaupunkeja, kauppaloita ja maalaiskuntia koskeva faktorianalyysi on osoittanut, että väestön rakennetta, ammattirakennetta ja muuttoliikettä koskevat muuttujat voidaan tiivistää kolmeksi perusulottuvuudeksi. Nämä ovat pienperheisyys, muuttoliike ja kaupunkimaisuus. Kun perustekijät ovat toisistaan suhteellisen riippumattomia, voidaan niitä käyttää kuvattaessa eri yhdyskuntien sosiaalista rakennetta. Laskemalla regressiomatriisi voidaan kullekin yhdyskunnalle laskea faktoripistemäärät eri ulottuvuuksilla. Näitä voidaan edelleen käyttää analyyttisina käsitteinä testattaessa erilaisia ekologisia hypoteeseja. Tämä työ on parhaillaan käynnissä. Sitten kun vuoden 1960 väestölaskennan tulokset ovat valmistuneet ja samanlainen analyysi on suoritettu, päästään vertaamaan eri ulottuvuuksien rakenteellisia muutoksia. 


\section{Liite. Variaabeliluettelo ja alimmat sekä ylimmät luokat}

1. Sähkövalolla varustettuja huoneistoja 100:aa asuinhuoneistoa kohden $0=0.0-9.9 ;--; 9=90.0-100$

2. Yksinäisruokakuntia 100:aa ruokakuntaa kohden $0=0.0-4.9 ;---; 6=30.0-34.9$

3. Henkilöitä 100 :aa perhettä kohden $0=470-490 ;---; 8=310-329$

4. Käytettävissä olevat tulot työikäistä kohden (1000 mk) ${ }^{1}$ $0=60-79 ;-\cdots ; 8=220-239$

5. Yhden huoneiston asuinrakennuksia 100:aa asuinhuoneistoa kohden $0=90.0-100 ;--; 9=0.0-9.9$

6. Talon tai huoneiston omistajia 100:aa asuinhuoneistoa kohden $0=90.0-100 ;--; 9=0.0-9.9$

7. Maa- ja metsätaloudessa toimivia ja heidän perheenjäseniään 100:aa asukasta kohden $0=90.0-100 ;--; 9=0.0-9.9$

8. Teollisuus- ja käsityöammateissa toimivia ja heidän perheenjäseniään 100:aa asukasta kahden

$0=0.0-9.9 ;--\quad ; 9=90.0-100$

9. Asukkaita maa-km² kohden $0=0.0-4.9 ;-\cdots ; 7=600.0-\mathrm{w}$

10. Kauppa-, liikenne- ja palveluväestö ja perheenjäsenet 100:aa asukasta kohden $0=0.0-9.9 ;--; 9=90.0-100$

11. Työikäisiä (15-64-vuotiaita) 100:aa asukasta kohden $0=52.5-54.9 ;--\quad ; 7=70.0-72.4$

12. Työikäisiä miehiä (15-64-vuotiaita) 100:aa työikäistä kohden $0=55.0-57.4 ;--\quad ; 6=40.0-42.4$

13. 0-4-vuotiaita 100:aa 15-44-vuotiasta naimisissa olevaa naista kohden $0=160.0-\mathrm{w} ;---; 7=55.0-69.9$

14. Asuinpaikkakunnalla syntyneitä 100:aa asukasta kohden $0=90.0-100 ;--\quad ; 8=10.0-19.9$

15. Siirtoväkeä 100:aa asukasta kohden $0=0.0-4.9 ;--\quad ; 6=30.0-34.9$

16. Johtajia ja toimihenkilöä 100:aa ammatissa toimivaa kohden $0=0.0-4.9 ;-\cdots ; 9=45.0-\mathrm{w}$

17. Kuntaan ja kunnasta muuttaneita 1000 :a asukasta kohden 2 $0=0.0-19.9 ;--\quad ; 9=180.0-199.9$

18. Miehiä 100:aa asukasta kohden $0=52.5-54.9 ;--; 5=40.0-42.4$

19. Ahtaasti asuttuja huoneistoja 100:aa asuinhuoneistoa kohden $0=60.0-69.9 ;-\cdots ; 6=0.0-9.9$

20. Keskikoulututkinnon vv. $1954-56$ suorittaneiden osuus vastaavasta ikäluokasta ${ }^{3}$ $0=0.0-4.9 ;--; 9=45.0-\mathrm{w}$

1 Wahlbeck, Lars. Om inkomstnivåns geografi i Finland år 1950. II, bilaga 5, L.

2 Suomen virallinen tilasto VI. Väestötilastoa. A: 107. Väestötutkimukset vuonna 1951. Helsinki 1953.

3 Ensiaineisto: Helsingin yliopiston maantieteen laitos. 
Liitetaulu 1. Korrelaatiomatriisi.

Appendix Table 1. The Correlation Matrix.

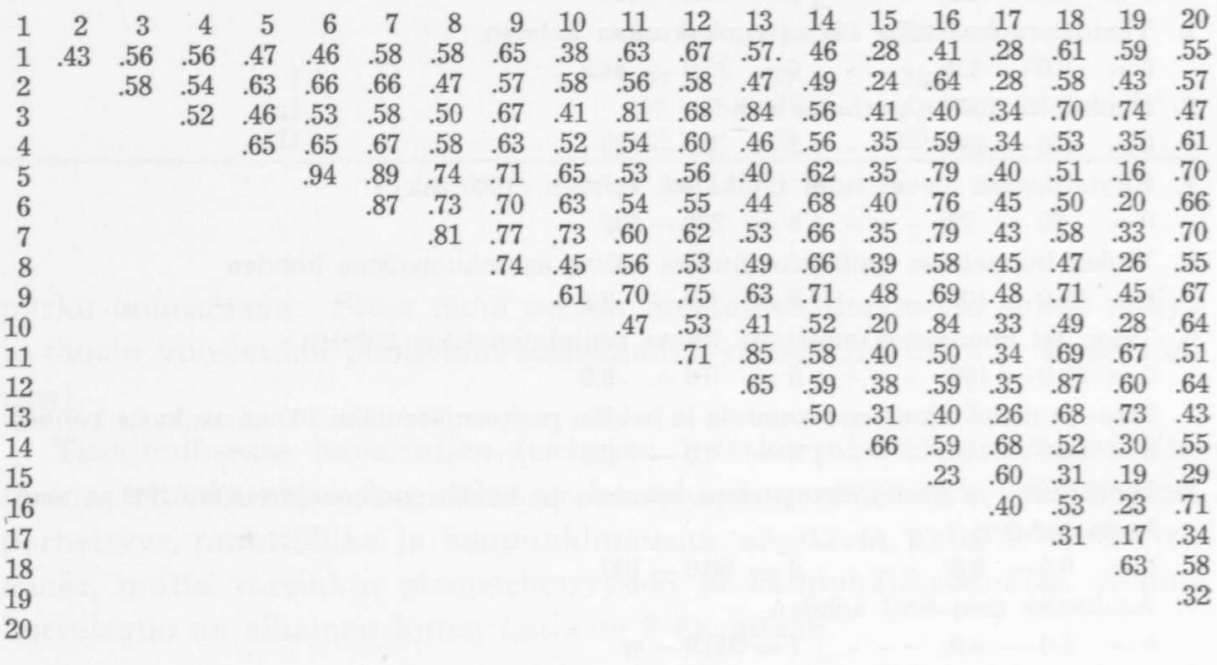

Li it eta u lu 2. Sentroidifaktorimatriisi.

Appendix Table 2. The Centroid Factor Matrix.

\begin{tabular}{rrrrr}
\hline & I & II & III & \multicolumn{1}{c}{$\mathrm{h}^{2}$} \\
1 & .70 & .18 & -.08 & .53 \\
2 & .71 & .05 & .27 & .58 \\
3 & .78 & .36 & -.22 & .79 \\
4 & .73 & -.08 & .09 & .55 \\
5 & .81 & -.36 & .29 & .87 \\
6 & .82 & -.35 & .19 & .83 \\
7 & .87 & -.25 & .18 & .85 \\
8 & .76 & -.25 & -.12 & .65 \\
9 & .88 & -.04 & -.05 & .78 \\
10 & .70 & -.13 & .38 & .65 \\
11 & .81 & .34 & -.19 & .81 \\
12 & .83 & .26 & .09 & .76 \\
13 & .73 & .43 & -.22 & .77 \\
14 & .78 & -.28 & -.32 & .79 \\
15 & .50 & -.22 & -.47 & .52 \\
16 & .77 & -.35 & .38 & .86 \\
17 & .53 & -.31 & -.37 & .51 \\
18 & .78 & .33 & .09 & .73 \\
19 & .56 & .59 & -.16 & .69 \\
20 & .75 & -.10 & .26 & .64 \\
\hline
\end{tabular}




\section{Kirjallisuus}

Alameri, Rolf. Muutamia havaintoja mies- ja naisenemmyydestä Suomen maalaiskunnissa vuosina 1910-1950. Väestöntutkimuksen vuosikirja VI-1960.

Allardt, Erik \& Littunen, Yrjö. Sosiologia. Porvoo 1961.

Anderson, Theodore R. \& Egeland, Janice A. Spatial Aspects of Social Area Analysis. American Sociological Review Vol. 26, 3, 1961.

Van Arsdol Jr., Maurice D., Camilleri, Santo F. \& Schmid, Calvin F. The Generality of Urban Social Area Indexes. American Sociological Review Vol. 23, 3, 1958.

Hartman, Tor \& Puumalainen, Pentti. Aviollisen hedelmällisyyden vaihteluista Suomessa. Väestöntutkimuksen vuosikirja VI-1960.

Hustich, Ilmari. Suomen taloudellinen aluejako. Oma maa 8, Porvoo 1960.

Jonassen, Christen T. Functional Unities in Eighty-Eight Community Systems. American Sociological Review Vol. 26, 3, 1961.

Markkanen, Touko. Faktoriluvun määrääminen Ahmavaara-Markkasen faktorimallin pohjalta. Alkoholipoliittinen Tutkimuslaitos. Moniste n:o 1. 1960.

Pulkkinen, Terho. Työttömyyden levinneisyys. Sosiaalipoliittisen yhdistyksen julkaisuja 4. Helsinki 1956.

Purola, Tapani. Maassamuuton voimakkuudesta ja suuntautumisesta Suomessa vuosina 1951-1955. Väestöntutkimuksen vuosikirja VI-1960.

Shevky, Eshref \& Bell, Wendell. Social Area Analysis. Stanford 1955.

Vahervuo, Toivo \& Ahmavaara, Yrjö. Johdatus faktorianalyysiin. Porvoo 1958.

Wahlbeck, Lars. Om inkomstnivåns geografi i Finland år 1950. I och II. Vasa 1955.

\section{Summary:}

\section{Dimensions of Ecological Differentiation in Finnish Communes}

\section{By PAAVO PIEPPONEN}

Population Research Institute

The purpose of the investigation was to determine dimensions of ecological differentiation in Finland. Factor analysis was used in examining twenty census variables from the year 1950, as itemized in table 1 of the text (p. 39). The unit of analysis was the local Finnish commune, of which there were 549 at the time of the census.

Factor analysis was carried out by Thurstone's centroid method on the basis of product-moment correlation coefficients, shown here in table 1 of the appendix (p. 44). The centroid factor matrix with communalities appears from table 2 of the appendix (p. 44). Rotation was carried out by Ahmavaara's method, a description of which has been published only in Finnish. Its result, the primary factor matrix, is shown in table 1 of the text (p. 39). Interpretation of the factors from this matrix yielded the following results:

Factor I. This factor has loadings .30 or higher on nine variables which are measures of family and population structure and of housing standard. Communities with low scores on this factor are characterized by large families, high fertility, and a low proportion of working-age population and of women. This factor can most accurately be termed $»$ Familism». 
Factor II. This is clearly a Migration factor, with high loadings on all mobility variables, viz. the proportion of displaced persons, in- and out-flow migration, and the proportion of persons living in the commune in which they were born.

Factor III. Judging from the nature of variables involved here, this is the factor of Urbanism. High loadings on occupational variables, the lack of one-family houses and owner-occupied homes, high school attendance, households with one person, high income and high population density are all characteristics of urban social structure and urban ways of life. This could also be called the »general» factor. Of the twenty variables, fourteen have significant loadings. However, the lack of significant loadings on some family and migration variables indicates that Familism and Migration are differentiated from Urbanism.

Table 2 of the text (p. 42) shows the amount of intercorrelations between factors. Multiple correlations of the factors with other factors are: Factor I, .375; Factor II, .502; Factor III, .417. The amounts of independent variance are, accordingly, 86, 75, and $83 \%$. 